\title{
PENENTUAN WAKTU KONTAK DAN pH OPTIMUM PENYERAPAN METILEN BIRU MENGGUNAKAN ABU SEKAM PADI
}

\author{
Anung Riapanitra, Tien Setyaningtyas, Kapti Riyani \\ Jurusan Kimia, Program Sarjana MIPA Unsoed Purwokerto
}

\begin{abstract}
Dyes are widely used for colouring in textile industries, significant losses occur during the manufacture and processing of the product, and these lost chemical are discharged in surrounding effluent. Adsorption of dyes is an effective technology for treatment of wastewater contaminated by the mismanaged of different types of dyes. In this research, we investigated the potential of rice husk ash for removal of methylene blue dyeing agent in aqueous system. The aim of this research is to find out the optimum contact time and $\mathrm{pH}$ on the adsorption of methylene blue using rice husk ash. Batch kinetics studies were carried out under varying experimental condition of contact time and $\mathrm{pH}$. An adsorption equilibrium condition was reached within 10 minutes and the optimum condition for adsorption was at $\mathrm{pH} 3$. The adsorption of methylene blue was decreasing with decreasing the solution $\mathrm{pH}$ value.
\end{abstract}

Keywords: methylene blue, adsorption, contact time, $\mathrm{pH}$

\section{PENDAHULUAN}

Zat warna metilen biru digunakan secara luas pada industri tekstil dan menjadi perhatian besar dalam proses pengolahan limbah karena warnanya yang sulit diuraikan. Senyawa ini bersifat toksik, menyebabkan mutasi genetik dan berpengaruh pada reproduksi. Senyawa ini memiliki rumus molekul $\mathrm{C}_{16} \mathrm{H}_{18} \mathrm{ClN}_{3} \mathrm{~S} .3 \mathrm{H}_{2} \mathrm{O}$ dengan bobot molekul 373,91 gram $/ \mathrm{mol}$, berwarna hijau tua, tidak berbau dan stabil dalam udara serta mudah larut dalam air (larutannya berwarna biru tua), kloroform dan alkohol. (Hawley, 1981).

Salah satu cara yang dapat digunakan untuk mengurai limbah cair zat warna adalah dengan metode adsorbsi. Adsorbsi merupakan suatu teknik yang efisien untuk menghadapi masalah kontaminasi limbah cair domestik dan industri, karena dapat menghilangkan bau serta menurunkan kadar zat warna dari larutan dengan sempurna tanpa mengubahnya menjadi senyawa yang lebih berbahaya. Selain itu penggunaan adsorben memiliki beberapa keuntungan diantaranya : memiliki poripori yang luas, hidrofob, stabil dalam temperatur tinggi, tidak memiliki aktivitas katalitik dan mudah diregenerasi (Wahab et al, 2005). Bahan adsorben yang sering digunakan antara lain karbon aktif, silika gel, zeolit, tanah diatome dan abu layang, tetapi bahan tersebut relatif mahal dan sukar diperoleh (Adamson,1990). Selama beberapa dekade penelitian telah dilakukan secara mendalam untuk mengembangkan material adsorben yang inovatif dan menjanjikan untuk memecahkan masalah kontaminan limbah cair industri. Hal tersebut mendorong para peneliti untuk mencari bahan yang lebih efisien, ekonomis dan praktis, salah satunya adalah sekam padi dari limbah pertanian yang merupakan sumber adsorben baru dan murah (Mahvi A.H et al, 2004).

Sekam padi adalah limbah pertanian yang dihasilkan sebagai produk samping dari industri pengolahan padi. Penggunaan sekam padi sebagai 
biomassa akan menyelesaikan masalah pembuangan limbah serta akses menuju material yang lebih murah untuk adsorbsi pada sistem kontrol untuk limbah perairan.

Dewasa ini keberadaan abu sekam padi belum mendapat perhatian dan penggunaannya hanya terbatas untuk beberapa keperluan sederhana misalnya untuk abu gosok, bahkan di beberapa tempat sekam padi dibuang dan dianggap sebagai bahan yang kurang bermanfaat. Padahal abu sekam padi merupakan bahan yang sangat potensial sebagai bahan penyerap logam berat dalam air

Abu sekam padi dapat digunakan sebagai adsorben karena selain merupakan material berpori juga mempunyai gugus aktif yaitu $\mathrm{Si}-\mathrm{O}-\mathrm{Si}$ dan Si-OH (Siriluk dan Yuttapong, 2005). Menurut Chen dan Chang (1991) kandungan silika $\left(\mathrm{SiO}_{2}\right)$ dalam abu sekam padi mencapai 80 - $90 \%$. Pada saat sekam padi terbakar sekitar $20 \%$ dari sekam padi berubah menjadi abu. Abu sekam padi mempunyai lebih dari $95 \%$ berat silika dengan porositas tinggi dan luas permukaan yang luas karena merupakan kerangka dan struktur seluler (Mahvi et al, 2004). Penelitian-penelitian sebelumnya menunjukkan adanya pengaruh $\mathrm{pH}$ dan waktu kontak yang signifikan terhadap proses adsorbsi. Berdasarkan pernyataan tersebut maka dalam penelitian ini mencoba untuk mengkaji pengaruh $\mathrm{pH}$ dan waktu kontak abu sekam terhadap adsorbsi metilen biru.

\section{METODE PENELITIAN \\ Pembuatan Abu Sekam Padi}

Sampel sekam padi diperoleh dari daerah Sokaraja. Sekam padi sebanyak 10 gram dimasukan dalam cawan pengabuan yang telah diketahui bobotnya. Pengabuan dilakukan dalam tanur pada suhu $600^{\circ} \mathrm{C}$ selama 4 jam hingga seluruhnya menjadi abu. Cawan didinginkan dalam eksikator, dihaluskan dan diayak dengan ukuran partikel 100 mesh, kemudian ditimbang.

\section{Penentuan Panjang Gelombang Maksimum Zat Warna Metilen Biru}

Larutan baku zat warna metilen biru 1000 ppm disiapkan dengan melarutkan 0,5 gram zat warna metilen biru pada $500 \mathrm{~mL}$ aquades. Larutan eksperimen disiapkan dari $2 \mathrm{~mL}$ larutan baku yang diencerkan hingga volume 100 $\mathrm{mL}$ untuk mendapatkan konsentrasi 20 ppm. Pengukuran panjang gelombang maksimum dilakukan pada panjang gelombang 400-700 nm dengan spektrofotometer UV-Vis.

\section{Penentuan Waktu Kontak Optimum}

Sebanyak 0,1 gram abu sekam dalam $25 \mathrm{~mL}$ larutan eksperimen, diatur pada $\mathrm{pH} 7$ dengan penambahan buffer phosphat, dikocok dengan variasi waktu kontak 10, 20, 30, 40, 50 dan 60 menit. Setelah pengocokan selesai larutan disaring dan filtrat diukur absorbansinya pada panjang gelombang maksimum.

\section{Penentuan pH Optimum}

Abu sekam sebanyak 0,1 gram dikocok dalam $25 \mathrm{~mL}$ larutan eksperimen pada waktu kontak optimum diujicobakan dengan variasi $\mathrm{pH} \mathrm{3,} \mathrm{4,} \mathrm{5,} \mathrm{6,} 7$ dan 8 . Kemudian diukur absorbansinya pada panjang gelombang maksimum, dibuat kurva hubungan absorbansi dengan $\mathrm{pH}$.

\section{HASIL DAN PEMBAHASAN}

Adsorpsi metilen biru menggunakan abu sekam padi dilakukan untuk mengetahui potensi abu sekam padi dalam penanganan limbah zat warna dalam sistem perairan. Adsorpsi metilen biru dalam sistem perairan diteliti dengan mempelajari parameter fisikokimia yaitu waktu kontak optimum dan $\mathrm{pH}$ optimum.

\section{Penentuan Panjang Gelombang} Maksimum Zat Warna Metilen Biru

Penentuan nilai panjang gelombang maksimum dilakukan pada range panjang gelombang 400-700 nm dengan spektrofotometer UV-Vis disajikan pada Gambar 1. 


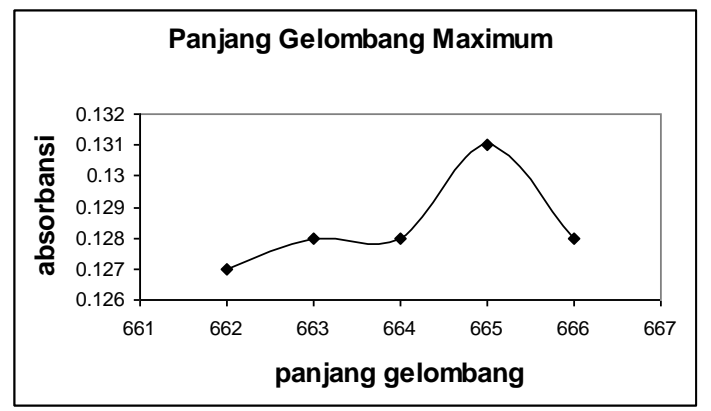

Gambar 1. penentuan absorbansi dan panjang gelombang maksimum zat warna metilen biru

Dari Gambar 1, dapat dilihat bahwa panjang gelombang zat warna metilen blue yang memberikan absorbansi terbesar adalah pada $665 \mathrm{~nm}$. Panjang gelombang inilah yang kemudian digunakan sebagai acuan untuk pengukuran pengaruh waktu kontak dan $\mathrm{pH}$.

\section{Penentuan Waktu Kontak Optimum}

Data adsorpsi penyerapan metilen biru pada waktu kontak optimum dengan penggunaan sebanyak 0,1 gram abu sekam dalam $25 \mathrm{~mL}$ larutan eksperimen 20 ppm, dilaksanakan pada pH 7. Hasil percobaan menunjukkan bahwa waktu kesetimbangan yang diperlukan untuk penyerapan metilen biru oleh abu sekam padi adalah 10 menit dimana konsentrasi metilen biru yang terserap mencapai 3,8 ppm. Waktu kesetimbangan yaitu waktu dimana laju adsorpsi sama dengan laju desorpsi. Dari data ini menunjukkan bahwa waktu yang dibutuhkan untuk penyerapan metilen biru oleh adsorben abu sekam padi cukup cepat. Gambar 2 menunjukkan pengaruh waktu kontak terhadap konsentrasi metilen biru yang terserap.

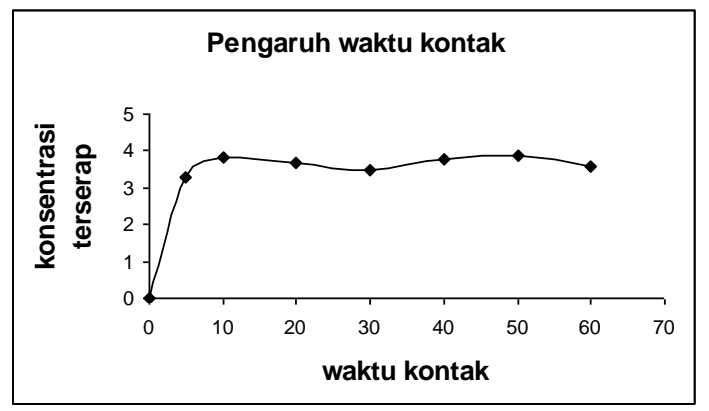

Gambar 2. Pengaruh waktu kontak terhadap adsorpsi metilen biru oleh abu sekam padi

\section{Penentuan pH Optimum}

Adsorpsi metilen biru oleh abu sekam padi dalam larutan bergantung dari $\mathrm{pH}$ larutan tersebut, dimana $\mathrm{pH}$ akan mempengaruhi muatan permukaan adsorben, derajat ionisasi dan spesi apa saja yang dapat terserap dalam adsorpsi tersebut. Adsorpsi metilen biru oleh abu sekam diujicobakan dengan variasi $\mathrm{pH} 3$, 4, 5, 6, 7 dan 8 pada larutan eksperimen dan waktu kontak optimum. kemudian diukur absorbansinya pada panjang gelombang maksimum, dibuat kurva hubungan konsentrasi terserap dengan $\mathrm{pH}$.

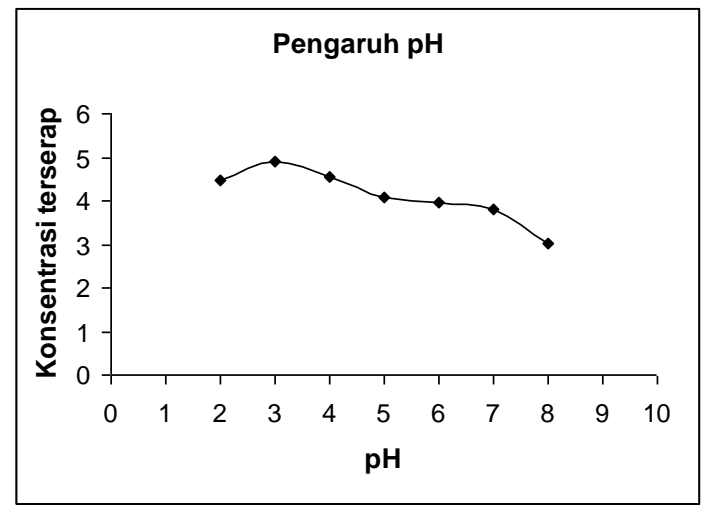

Gambar 3. Pengaruh pH terhadap konsentrasi metilen biru yang terserap

Dari hasil percobaan diketahui bahwa konsentrasi zat warna metilen biru yang terserap berkurang seiring dengan kenaikan pH. Mulai dari pH 2 konsentrasi 
metilen biru yang terserap meningkat hingga pada $\mathrm{pH} 3$, namun setelah $\mathrm{pH} 3$ konsentrasi metilen biru yang teradsorpsi terus menurun hingga akhir seri yaitu $\mathrm{pH}$ 8. Penyerapan tertinggi berlangsung pada saat $\mathrm{pH}$ 3. Hal ini menunjukkan keterkaitan antara nilai $\mathrm{pH}$ dengan senyawa yang diadsorpsi yaitu metilen biru. Hal ini dapat dikarenakan pada $\mathrm{pH}$ yang lebih tinggi metilen biru membentuk garam yang mengionisasi gugus pergi bermuatan negatif dari metilen biru yaitu $\mathrm{Cl}^{-}$. Pada saat yang bersamaan kehadiran ion $\mathrm{OH}^{-}$dari adsorben abu sekam padi akan menghambat penyerapan dari metilen biru dalam bentuk ion karena akan terjadi repulsi yang terjadi karena muatan yang sama antara daerah di sekitar permukaan pori-pori adsorben dan muatan dari metilen biru itu sendiri. Hal ini akan menyulitkan metilen untuk masuk dan terserap ke dalam pori-pori adsorben. $\mathrm{pH}$ juga mempengaruhi sifat permukaan metilen biru. Pada saat $\mathrm{pH}$ rendah maka banyaknya ion $\mathrm{OH}^{-}$dari gugus siloksan dan silanol metilen biru akan mengelilingi permukaan metilen biru dan dapat terikat ke gugus $\mathrm{N}$ yang terdapat dalam metilen biru. Hal ini akan meningkatkan interaksi metilen biru dengan adsorben dengan semakin besarnya gaya tarik-menarik yang terjadi.

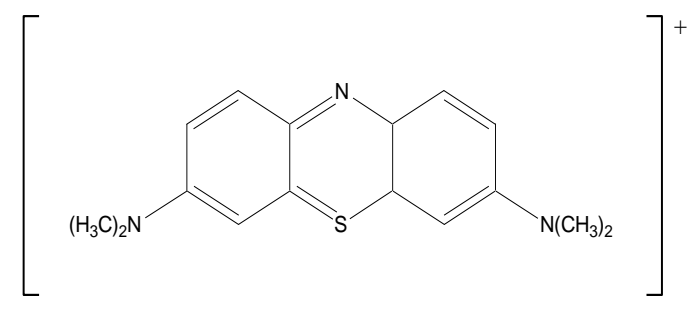

Gambar 4. Struktur ion Metilen Biru

\section{KESIMPULAN}

Pada penelitian ini kemampuan abu sekam padi sebagai adsorben untuk menyerap zat warna metilen biru diteliti sebagai fungsi waktu kontak optimum dan $\mathrm{pH}$ optimum. Kapasitas adsorpsi dari abu sekam padi ternyata bergantung dari pH larutan dan waktu kontak optimum. Waktu kontak yang diperlukan untuk waktu kesetimbangan yaitu selama 10 menit dan $\mathrm{pH}$ optimum pada $\mathrm{pH} 3$. konsentrasi metilen biru yang teradsorpsi makin menurun seiring dengan menurunnya $\mathrm{pH}$.

\section{DAFTAR PUSTAKA}

Adamson, A. W., 1990, Physical Chemistry of Surface, 5th edition, John Willey and Sons, Toronto.

Chen, J. M. dan Chang F. W., 1991, The Chlorination Kinetics of Rice Husk, Ind. Eng. Chem. Res.,30, 2241-2247

Hawley, 1981, Condensed Chemical Dictionary, Eleventh ed. Van Nortrand Reinhold, New York.

Mahvi, A.H, A. Maleki dan A. Eslami, 2004, Potential of Rice husk and Rice husk Ash for Phenol Removal in Aqueous System. "American Journal of Applied Sciences" 1(4), 321-3226.

Siriluk, C. dan Yuttapong, S. 2005. Structure of Mesoporous MCM-41 Prepared from Rice Husk Ash. The $8^{\text {th }}$ Asian Symposium On Visualization, Chiangmai, Thailand, 23-27 May 2005, Paper Number n $1-7$.

Wahab, O. A., Nemr, A. E., Sikaily, A.E., dan Khalded, A, 2005, Use of Rice Husk for Adsorption of Direct Dyes from Aqueous Solution: A case Study of Direct F. Scarlet, Egyptian Journal of Aquatic Research, 31, 2005. 